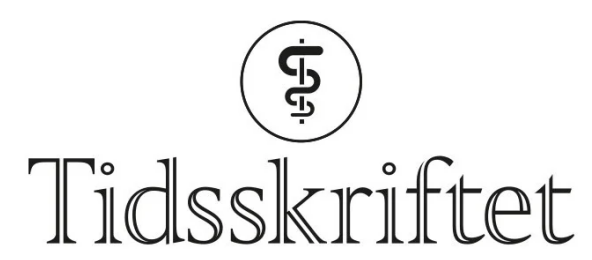

DEN NORSKE LEGEFORENING

\title{
Nyttig og grundig veileder i barneradiografi
}

\section{ANMELDELSER}

\section{BJARNE SMEVIK}

Enhetsoverlege, Bilde- og intervensjonsklinikk

Oslo universitetssykehus

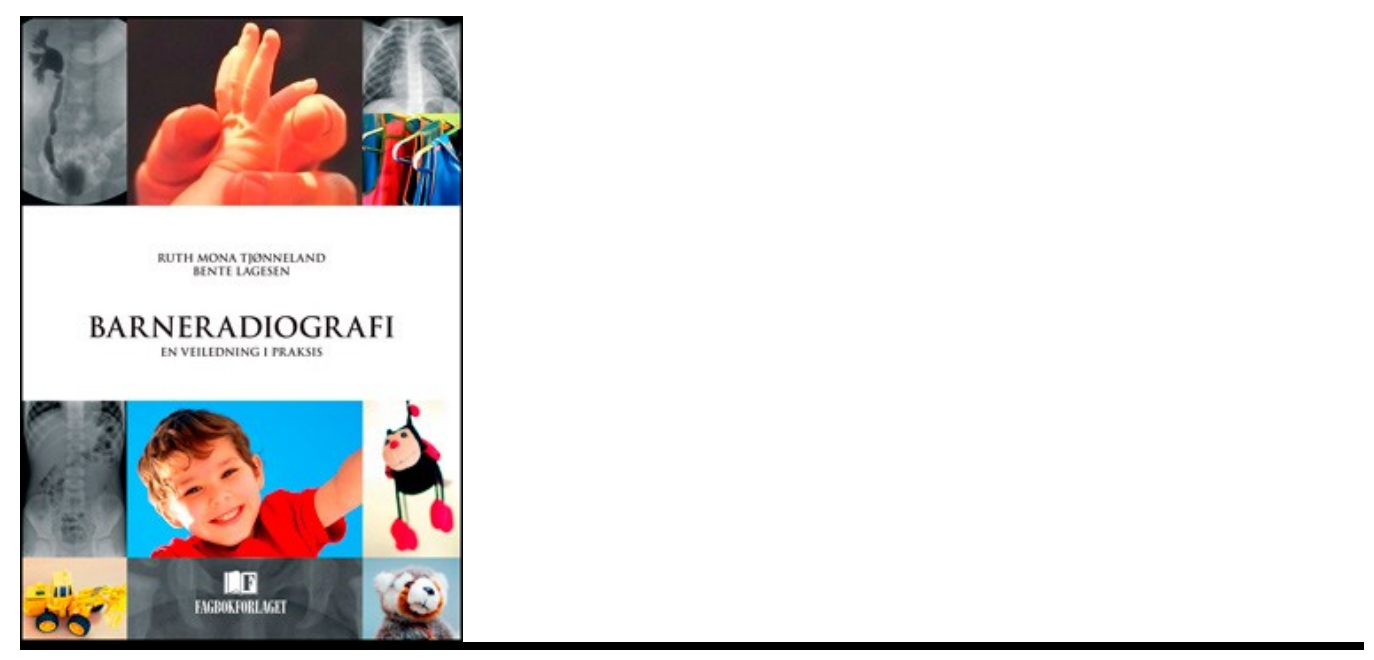

Tjønneland, Ruth Mona

Lagesen, Bente

Barneradiografi

En veiledning i praksis. 229 s, tab, ill. Bergen: Fagbokforlaget, 2013. Pris 279

ISBN 978-82-450-1182-1

Målgruppen er primært radiografer, både under utdanning og i arbeid ved norske sykehus. Treningsgrunnlaget som skal til for å få utført en god røntgenundersøkelse av barn, blir ofte spinkelt utenom spesialavdelinger, og denne boken er et konkret bidrag til å høyne kvaliteten på nødvendige utredninger av barn. Forfatterne har arbeidet med barneradiografi i mange år, og de deler sine erfaringer med barn "på røntgen», med intensjon om at røntgenundersøkelsen skal bli vellykket både for barnet, foresatte og personalet. 
Boken er bygd opp med oversiktlige kapitler som omhandler barns rettigheter, hva som skiller barn fra voksne pasienter, bruk av immobilisering, sedasjon og kontrastmidler. Strålehygieniske forhold er grundig diskutert i tråd med at temaet er helt sentralt $i$ all virksomhet der barn utsettes for ioniserende stråling.

Forfatterne har lagt stor vekt på riktig håndtering av barn og pårørende i en situasjon som kan være krevende for både besøkende og røntgenpersonalet. Hele gjennomføringen av en radiologisk prosedyre gjennomgås, fra forberedelse av undersøkelsen på laboratoriet, til mottak av pasienten med følge og orientering om hvorfor og hvordan unders $\varnothing$ kelsen foregår. Dette er en praktisk veileder, og tips for radiografen om posisjonering, holdeteknikk, eksponeringsparametere, innblending, stråleretning, valg av kontrastmiddel osv. får en fremtredende plass. De aller fleste radiologiske undersøkelsestyper som barn kan gjennomgå ved norske sykehus, omtales og illustreres med fotografier, røntgenbilder og strektegninger som er tydelige og velvalgte. Spesielle kapitler omhandler computertomografi (CT) og magnetisk resonansundersøkelser (MR) av barn.

Dette er den første samlede beskrivelsen av barneradiografi på norsk, og det er etter min mening en bok som oppfyller forfatternes intensjon om å levere et praktisk og nyttig bidrag til at barn behandles på en god måte når nødvendige radiologiske undersøkelser må utføres.

Den bør finnes ved alle norske røntgenavdelinger og barneavdelinger og bør også inngå som et viktig grunnlag i utdanningen av norske radiografer. Videre kan boken være nyttig som et orienterende oppslagsverk for alle leger som henviser barn til røntgenundersøkelser, og en god kilde til informasjon for barnesykepleiere som skal forberede barn for røntgenundersøkelse, og eventuelt følge barn til røntgenavdelingen.

Publisert: 25. februar 2014. Tidsskr Nor Legeforen. DOI: 10.4045/tidsskr.13.1544

(C) Tidsskrift for Den norske legeforening 2023. Lastet ned fra tidsskriftet.no 26. april 2023. 